\title{
Dziedzictwo kulturowe na Bałkanach. Pomiędzy prawosławiem a islamem
}

\author{
Islam i muzulmanie w kulturze, literaturze i jezykach Stowian \\ Poludniowych, red. Anetta Buras-Marciniak, Wydawnictwa \\ Uniwersytetu Lódzkiego, Łódź 2016, 282 s.
}

Prezentowany tom zawiera dwadzieścia cztery referaty wygłoszone przez uczestników międzynarodowej konferencji naukowej o tym samym tytule, która odbyła się w Uniwersytecie Łódzkim w dniach 18-19 lutego 2016 roku. Konferencja zorganizowana przez Katedrę Filologii Słowiańskiej, Katedrę Bliskiego Wschodu i Północnej Afryki oraz Centrum Badań nad Historią i Kulturą Basenu Morza Śródziemnego i Europy Południowo-Wschodniej im. prof. Waldemara Cerana „Ceraneum” skupiła badaczy różnych dyscyplin z licznych ośrodków naukowych w kraju i z zagranicy, a dowodem jej znaczenia są zaprezentowane w zbiorze artykuły. Podjęto w nim kwestie współistnienia wyznawców religii islamskiej, chrześcijańskiej i innych pod panowaniem tureckim, międzykulturowego dialogu (często niełatwego) kultur islamu i bizantyjsko-słowiańskiej na tym obszarze. Islam został przedstawiony nie tylko jako filozofia życia, ale przede wszystkim w ujęciu literackim oraz społeczno-politycznym w perspektywie historycznej bliższej i dalszej.

Praca jest tym bardziej cenna ze względu na walor aktualności, zwłaszcza w obliczu dzisiejszej sytuacji geopolitycznej, na którą można dzięki niej spojrzeć z perspektywy wielu wieków wstecz. Muzułmanie są drugą po chrześcijanach największą grupą religijną na świecie. Stanowią około 17\% ludzkości i przybywa ich około $3 \%$ rocznie ${ }^{1}$. Bieżące, nowe zjawiska na scenie politycznej, prawnej, bankowej, handlowej, muzycznej, socjologicznej,

\footnotetext{
${ }^{1}$ Leksykon dla dziennikarzy. Nie bój się Islamu, <http://www.wiez.com.pl/islam/index. php?id=20>, 26.01.2017.
} 
medialnej, propagandowej będą z pewnością łatwiejsze do zrozumienia po lekturze tej interdyscyplinarnej publikacji. Choć dotyczy ona określonego wycinka przestrzeni, to pewne mechanizmy wypracowane w dwóch omawianych kulturach, $\mathrm{tj}$. islamu i krajów południowosłowiańskich, w wyniku wzajemnego przenikania, można odnaleźć również we współczesnym świecie pod inną szerokością geograficzną. Czy kształtujące się stereotypy: Araba w sztuce etnosów bałkańskich, wyznawcy prawosławia w kulturze islamu, słowiańskich muzułmanów (Boszniaków, Goran, Torbeszów, Pomaków) w kulturze Słowian Południowych, można odnaleźć dzisiaj w kulturze Europy Zachodniej? Czy ich echa rezonują dzisiaj? Czy w czasie debaty okołopolitycznej, gdy jest mowa o ściślejszej współpracy z krajami nie Europy Zachodniej, nie pobrzmiewa powątpiewanie nie tylko $\mathrm{w}$ posiadanie przez kraje bałkańskie struktur państwowych, ale i infrastruktury?

Swoistą próbą odpowiedzi na powyższe pytania są zamieszczone w omawianym tomie artykuły badaczy z Polski oraz z Bośni i Hercegowiny. I tak znalazły się w nim rozważania poświęcone muzułmańskiej i arabskiej tradycji literackiej (m.in. Marka M. Dziekana, $Z$ dziejów literatury ,alhamijado” na Batkanach: Abdulvehab Ilhamija (1773-1821), Sanjina Kodricia Kako su Bošnjaci videli muslimanski Orijent i europski Zapad krajem 19. i početkom 20. stoljeća?, Murisa Bojramovicia Mevlud u bošnjačkoj književnosti, Adnana Kadricia Liminalno-heterogena poetika starije bošnjačke književnosti u kontekstu zapadnobalkanske kulturološke polifonije, Aidy Bajraktarević Slika Bošnjaka u autobiografskom diskursu „Sjećanja” Meše Selimovića, Alen Kalajdžija Tri rukopisna arebička ilmihala na bosanskom jeziku u XIX st., Magdaleny Garnczarskiej „Historia budująca o Barlaamie i Jozafacie" jako historia budujaca dla chrześcijan żyjacych pod islamskim panowaniem na przyktadzie miniatur wiviron cod. 463). Stały się one pretekstem przeprowadzonych na wybranych przykładach analiz poświęconych znaczeniu kultury tworzonej przez muzułmanów na terenach występowania wielu kultur. Stanowią też odbicie spojrzenia samego Orientu na świat Europy Zachodniej w przeszłości. W tym kontekście niezwykle cenny wydaje się tekst Krystyny Pieniążek-Marković (Chorwackie spotkania z kultura islamu $w$ dziewiętnastowiecznym podróżopisarstwie. We władzy stereotypów). Jak zauważa autorka: „Ogólny obraz Bośni wyłaniający się z kart chorwackich podróżników to zacofana, obca, mroczna, tajemnicza i niebezpieczna kraina, po której z trudem 
można się poruszać, zaiste «dzika Europa» bez dróg i mostów, skazująca wędrowca na tułaczkę po bezdrożach, nieustanne przebywanie w sytuacji granicznej, w stanie zagrożenia życia ze strony «dzikich ludzi» i niesprzyjającego klimatu" (s. 26). Krytykowanie kultury islamu przez Chorwatów - jak podkreśla autorka - ,jest rezultatem uprzedzeń, ideologii, planów politycznych oraz/lub postulatów modernistycznych" (s. 31). Dla Chorwatów europejska Turcja w zbiorowej pamięci, w literaturze i w relacji Pogled u Bosnu Matiji Mažuranicia, który przebywał tam na przełomie lat 1839 i 1840 niecałe dwa miesiące, to teren „całkowitego nieposzanowania mienia i życia ludzkiego, powszechności i bezkarności kradzieży, gwałtu, zbrodni”, a muzułmanie to „barbarzyńcy, groźni także dla siebie nawzajem” (s. 27). Bośnia w podróżopisarstwie chorwackim jest ukazana jako teren bardzo niebezpieczny dla chrześcijan. Ich nękanie, często prowadzące do śmierci, według Matiji Mažuranicia było „rodzajem muzułmańskiej rozrywki lub środka wiodącego do realizacji konkretnego celu" (s. 26). Autorka zwraca uwagę na zaskakująco drobiazgową ocenę Tkalčevicia dotyczącą Turczynek, ich budowy ciała, diagnozy złej kondycji fizycznej i psychicznej oraz oceny tradycyjnego kobiecego stroju muzułmanek, która również i dzisiaj pozostaje przedmiotem dyskursu o granicach i wyznacznikach tolerancji poszczególnych grup religijnych wobec siebie ${ }^{2}$. Krystyna Pieniążek-Marković określa funkcje, jakie miały spełniać teksty Chorwackich podróżników. Docierając do decydentów europejskich, powinny wpływać na uwolnienie Europy najpierw od Turków, później od śladów ich bytności, a następnie ,uwolnienie” ich od nich samych (ucywilizowanie) (s. 37). W tekście sygnalizowane są różne podmioty odczytywane jako „obcy” czy „inny”. Według Tkalčevicia „innym” jest Turek, a Ivan Kukuljević Sakcinski wskazuje, że dla wszystkich Bośniaków ucieleśnieniem „obcych” są Turcy Osmańscy (s. 29).

Kwestie współistnienia na tym samym obszarze zróżnicowanych kultur podejmuje również Lilla Moroz-Grzelak (Czarny Arab jako symbol obcości w świecie bohaterów poludniowosłowiańskich pieśni ludowych). $\mathrm{Na}$ podstawie serbskich analiz naukowych zaprezentowane zostały teorie powstania tej popularnej tytułowej postaci. Autorka skrupulatnie wyjaśnia

\footnotetext{
${ }^{2}$ Kwestie wyglądu kobiet i mężczyzn zamieszkujących Bałkany podejmowali w swych opisach podróżnicy Zachodni, o czym pisał w swoim studium Jezernik (2007).
} 
wielorakie znaczenia czerni w kulturze osmańskiej, która posiada zarówno pozytywne, jak i negatywne konotacje, skupiając się na tym drugim skojarzeniu. Opis czarnego Araba dotyczy zarówno jego cech zewnętrznych, jak i wewnętrznych oraz jego losu i śmierci. Autorka dostrzega subtelne odcienie niejednoznaczności tejże figury. Występowanie czarnego Araba w utworach ludowych Słowian Południowych - znacznej mierze Serbów, ale też Bułgarów i Macedończyków - oraz w folklorze albańskim na przestrzeni wieków - od najstarszych pieśni bohaterskich, przez średniowieczne po pieśni nowych czasów - zostało prześledzone pod kątem zmian, które zachodziły w jego obrazie. Figura czarnego Araba (Arap, Arapin [s. 78], Jovan Kursula [s. 84], Musa Kesedžija [s. 85]) uosabia zło, tureckie jarzmo, wroga, barbarzyńcę, nosiciela wartości całkowicie obcych, kulturę narzuconą, ,ciemiężcę uciśnionego ludu, nienawistnika, prześladowcy, grabieżcy, zaborcy i rozpustnika, antagonisty nękanych chrześcijan z Bałkanów" (s. 85). Czarnemu Arabowi skutecznie stawia opór i pokonuje go dzielny, sprytny słowiański bohater: serbski, bułgarski czy macedoński, uosabiający dobro, niezwyciężoność, własne wartości, rodzimą kulturę (,królewicz Marko, dzielny junak z Prilepu” [s. 81], „Chory Dojczin” [s. 82], Grujica, Karadjordje, Jerzy Czarny Petrović). Przedstawienie tych dwóch typów postaci w opozycji „swój-obcy, bohater miejscowy-przybysz” (s. 86) ukazuje stosunek chrześcijańskich Słowian Południowych do islamu wyznawanego przez mieszkańców Imperium Osmańskiego, które od 1371 roku opanowywało kolejne tereny w Europie. Czarny Arab w najstarszych pieśniach bohaterskich oraz w opowieści z II połowy XX wieku, stanowi również zagrożenie dla króla arabskiego, którego córkę chce poślubić. Figura czarnego Araba była właściwa dla obcej rodzimej kulturze dominacji tureckiej, złego wroga, który choćby w legendzie, ale zawsze przegrywał.

Na wartość zróżnicowanego świata Bałkanów zwraca uwagę Artur Stęplewski (Mehmed Sokolović jako postać literacka. Na marginesie powieści „Hamam Balkanija” Vladislava Bajaca), odnosząc się do prozy powieściowej Wschodu. Autor podejmuje próbę zmierzenia się ze stereotypem zacofanego, dzikiego, niedemokratycznego, kłótliwego, walczącego Wschodu w stosunku do lepszego, wartościowszego, nowocześniejszego hegemona - Zachodu w dziedzinie literatury. Artur Stęplewski wykazuje, że Wschód nie tylko dogonił i dorównał, ale ,wracając do tradycyjnych, własnych gatunków wyprzedził czołówkę" (s. 126), chociaż już po ogłoszeniu przez 
Zachód końca tradycyjnej powieści. Przykładem ilustrującym to osiągnięcie jest powieść Vladislava Bajaca Hamam Balkanija i jej główny bohater Bajica Sokolović (Mehmed-paša Sokolović/Sokollu). Autor uważa, że literatura Wschodu naśladuje literaturę Zachodu, stosując takie zabiegi, jak: obrazowa kompozycja tekstu jako odrzucenie logocentrycznej relacji języka i rzeczywistości czy historiozoficzna metafikcja, w rzeczywistości wracając do ,własnego kulturowego dziedzictwa” (s. 128). W artykule podkreśla, że literaturę Bliskiego Wschodu - a zwłaszcza jej najpopularniejsze gatunki: masnawi, baśnie i legendy - przystosowała powieść Zachodu do lokalnych kultur. Trudności stanowiły różne rozumienia fikcji, inny sposób percepcji polegający na opisywaniu świata z zewnątrz, w odróżnieniu od poznawania świata przez czytelnika powieści z wewnątrz, czyli oczami bohatera, nadmiernie rozbudowany psychologizm postaci w powieści, podczas gdy w literaturze Wschodniej o decyzjach życiowych decyduje kontakt z innymi ludźmi, doświadczenie. Natomiast narracja, która jest opowiadaniem, jest punktem stycznym powieści bałkańskiej i bliskowschodniej.

Kwestia zderzenia odmiennych kultur pozostawiła trwały ślad w pamięci historycznej i kulturowej na Bałkanach. Przypomina o tym Ewa Szperlik (Fascynujacy czy przerażajacy świat islamu w wybranych utworach chorwackich ilirystów i późnych romantyków?), zwracając uwagę na newralgiczne położenie Chorwacji, a więc między Wschodem a Zachodem, a nawet dwoma Wschodami (tj. kulturą bizantyjską i kulturą islamu), które determinuje przedstawianie świata islamu w literaturze bałkańskiej. Pochylając się nad dziełami autorów chorwackich: Ivana Mažuranicia Śmiercia Smail-agi Czengicia i Petara Preradovicia Mujezinem, nowelami Pobratimstvo i Dilber Hasan oraz poematem Luki Boticia Bijedna Mara, zauważa, że ,żaden z wymienionych autorów nigdy nie przekroczył wschodniej granicy, aby dotrzeć do świata, który stał się jego literacką inspiracją" (s. 108). Obraz świata islamu w wybranych utworach nie był jednolity, statyczny. Sytuacja polityczna wpływała na fascynację lub strach przed tym światem. O ile już w epoce średniowiecza pojawiają się zjawiska obronne akcentujące własną tożsamość Chorwatów i ewentualne koligacje $\mathrm{z}$ Zachodem, jak przedmurze, brama chrześcijaństwa i most między Zachodem a Wschodem, a co za tym idzie - obraz złego muzułmanina, o tyle dla ilirystów i romantyków temat walki chrześcijaństwa z islamem został porzucony, a „inny”, turecka Chorwacja i Bośnia 
stały się przedmiotem zainteresowania i akceptacji, a nawet fascynacji, obrastając pozytywnymi bądź negatywnymi stereotypami. Tym właśnie kwestiom poświęciła swój tekst Magdalena Rekść (Stereotypy na temat wyznawców islamu na obszarze byłej Jugosławii), która we wstępie zastrzegła, że nie bada autostereotypów wszystkich wspólnot muzułmańskich z obszaru byłej Jugosławii, m.in.: Albańczyków, Goran, Torbeszów, lecz ograniczy się tylko do Boszniaków, to w tekście odnosi się także do stereotypów Serbów o Boszniakach, Serbów o Słoweńcach, Serbów o Albańczykach, Chorwatów o wszystkich muzułmańskich mieszkańcach Bośni i Hercegowiny, Macedończyków o Albańczykach (Šiptarach), Słoweńców o imigrantach z republik dawnej Jugosławii. Poświęcając swą uwagę wzajemnym stereotypom na Bałkanach, autorka podaje ich różne definicje, mechanizmy rządzące procesem ich tworzenia nie tylko na przykładzie muzułmanów, ale także sąsiedzkiego postrzegania $\mathrm{w}$ innych rejonach Europy (stereotypy Polaków dotyczące Niemców, Rosjan i Ukraińców) oraz ich wpływu na podejmowane decyzje polityczne, na kształtowanie się ideologicznej płaszczyzny konfliktów zbrojnych, na zjawiska socjologiczne, takie jak: kontrtożsamość, terror stereotypów, dystans etniczny.

Stereotypizację dostrzega także w swoim artykule Sabina Giergiel (Zmiana modelu kulturowego w Serbii na przełomie XIX $i$ XX w. na podstawie opowiadania ,Ibisz-aga” Stevana Sremaca). Przywołuje ona i poddaje analizie odwrócony niejako stereotyp postrzegania Turka jako złego ${ }^{3}$. Odnosząc się do prozy serbskiego pisarza, wskazała na jego poglądy, że przemiany, które zaszły w wyniku europeizacji i narodowej emancypacji Serbów, są zgubne dla tradycyjnego porządku. W tytułowym opowiadaniu nie ma negatywnego obrazu muzułmanina. Serbowie w obliczu pojawienia się nowego ładu - obyczajów zachodnioeuropejskich opowiadają się za dotychczasowym swojskim, bliskim, dobrze znanym i przyjętym porządkiem, czyli tradycją turecką. Tym samym, jak zauważa autorka, jest to stanowisko zupełnie wyjątkowe w literaturze Słowian Południowych, czego powiedzieć nie można o późniejszych odzwierciedleniach najnowszych konfliktów na Bałkanach. Wskazuje na to tekst Moniki Skrzeszewskiej

${ }^{3}$ Ważny w tym kontekście jest stereotyp Turka w sąsiedniej Bułgarii opisany w artykule G. Szwat-Gyłybowej (1993: 71-76). 
(Wojna bośniacka (1992-1995) wedtug Dobricy Ćosicia jako przyktad antymuzutmańskiego dyskursu nacjonalistycznego).

Ważne miejsce w tomie zajmują zagadnienia religijne i społeczno-polityczne zróżnicowanego kulturowo sąsiedztwa na Bałkanach w ich kontekście historycznym. Uwagę swą tym problemom w różnym ujęciu poświęcili: Justyna Kroczak (Mistyczny rozwój człowieka na przykładzie hezychazmu i sufizmu), Anetta Buras-Marciniak Muzulmanie w Stowenii (zarys tematyczny), Marinko Zekić (Muslimanske zajednice u Europi i problem islamofobije), Agata Jawoszek (Boszniacka diaspora w Europie Zachodniej w świetle kryzysu imigracyjnego i rosnacej islamofobii. Media, tożsamość i polityka) czy Magdalena Ickiewicz-Sawicka (Bośniaccy muzutmanie [Boszniacy] w obliczu kryminogennego i radykalnego islamu na Batkanach - przypadek Bośni i Hercegowiny). Natomiast kwestię konfliktu, lecz z perspektywy kobiet, podejmuje Anna Modelska-Kwaśniowska (Kobiece doświadczenie traumy wojennej w powieści Jasminy Musabegović „Skretnice”). Szczególnie interesujący w tym miejscu wydaje się artykuł Wojciecha Szczepańskiego (Kilka uwag o konfliktach albańsko-serbskich na tle religijnym $w$ wilajecie kosowskim na przetomie XIX $i$ XX w. (wybrane przyktady). Zwraca on uwagę, że przełom XIX i XX w. obfitował w konflikty prawosławnych Serbów z Albańczykami - muzułmanami i chrześcijanami. Autor przedstawia kwestię wrogości mającej za podłoże nietolerancję religijną, zaś pozostałymi przyczynami są czynniki ekonomiczne i polityczne, ponieważ w systemie osmańskim status społeczności islamskiej różnił się od położenia nie-muzułmanów (s. 144). Autor poddaje analizie lata 1881-1901, 1902-1903, 1904-1907 i 1908-1912, których wydarzenia do dziś mają swoje reperkusje, i obszar nie tylko wilajetu kosowskiego, lecz także Metochię, wilajet monasterski (bitolski) oraz sandżaki prištiński i prizreński. Jak zauważa, konflikty dotykały także inne grupy etniczne: Czarnogórców, niesprzyjającą Albańczykom część Vlachów, Cyganów i Słowian macedońskich. W artykule zostają przywołane noty polityków charakteryzujących napiętą sytuację: Stojana Novakovicia posła Królestwa Serbii akredytowanego przy Porcie, serbskiego dyplomaty Svetislava Simicia (pseudonim P.O. - Pavle Orlović), habsburskiego ministra spraw zagranicznych Aloisa L. Ährenthala i serbskiego konsula w Prisztinie Simy J. Avramovicia.

O wartości zbioru stanowią także teksty poświęcone współczesnemu odbiciu zderzenia kultur w Internecie i języku autorstwa Katarzyny 
Bednarskiej (Muzutmanie $i$ islam $w$ stoweńskim korpusie językowym), Klaudii Chalczyńskiej i Artura Zaręby (Określenia migrantów i ich nacechowanie na polskich, bułgarskich i słoweńskich internetowych portalach informacyjnych) oraz Marii Cichońskiej (Gramatyka wyrazem narodowej tożsamości [na przykładzie „, Gramatyki języka bośniackiego” Dževada Jahicia, Senahida Halilovića, Ismaila Palicia]).

Zaprezentowany tom, ograniczając się do przestrzeni bałkańskiej i odnosząc się $\mathrm{w}$ tekstach poszczególnych autorów do rozmaitych zagadnień współistnienia zróżnicowanych kultur, stanowi doskonałe, naukowe ujęcie problematyki cywilizacyjnej. Zbiór prac zebranych pod wspólnym tytułem Islam i muzulmanie $w$ kulturze, literaturze i językach Stowian Poludniowych, pod redakcją Anetty Buras-Marciniak jest niezwykle cenną inicjatywą naukową, która pozwala na zapoznanie się ze zjawiskiem ciągłego przenikania się dwóch wielkich kultur na przestrzeni dziejów. Można poczuć jedynie niedosyt z ograniczonego obszaru geograficznego i braku nie-słowiańskich aspektów. Pojawiające się literówki wynikają zapewne $\mathrm{z}$ pośpiechu $\mathrm{w}$ dążeniu do wydania omawianego tomu w tym samym roku kalendarzowym co i konferencja, ale prezentowana w nim tematyka dotyka, poszerza i odkrywa kolejne zależności, relacje, mechanizmy związane $\mathrm{z}$ zagadnieniami islamu i muzułmanów w ujęciu historycznym wraz z odniesieniami do współczesności na terenie Słowiańszczyzny Południowej. $\mathrm{Z}$ całą pewnością publikacja ta stanowi kolejny materiał badawczy dla zainteresowanych tymi zagadnieniami, które w świetle dzisiejszej sytuacji geopolitycznej mogą dawać co najmniej podpowiedzi w próbach poszukiwania zrozumienia rozgrywających się aktualnie wydarzeń.

Matgorzata Dębowczyk

\section{Literatura}

Jezernik B., 2007, Dzika Europa. Bałkany w oczach zachodnich podróżników, przeł. P. Oczko, Kraków.

Szwat-Gyłybowa G., 1993, Stereotyp Turka w piśmiennictwie bułgarskim XIX stulecia a grzechy europejskiego orientalizmu, w: Kategoria narodu w kulturach stowiańskich, red. T. Dąbek-Wirgowa, A.Z. Makowiecki, Warszawa, s. 71-76. 